\title{
Standardization as emerging content in technology education at all levels of education
}

\author{
Dong Geun Choi · Henk J. de Vries
}

Published online: 20 January 2010

(C) The Author(s) 2010. This article is published with open access at Springerlink.com

\begin{abstract}
Integration of standardization into different levels of technology education has surfaced as a critical issue for educational practitioners and policy makers at national and regional (APEC, EU) level. In this paper, we describe and analyze empirical data collected from 118 educational experiences and practices about technology standards and standardization in 21 countries of a regional variety. Specifically, this research examines standardization education programs these countries have implemented, and explores suggestive indications for the design and development of an educational policy for standardization. Online surveys, offline interviews, face-to-face meetings and case studies have been used to determine the way these standardization education programs are segmented and implemented in different contexts. The findings are consolidated into a framework for standardization education. The framework presents an applicable combination of target groups (who), appropriate learning objectives (why), probable program operators (where), prospective contents modules (what), and preferred teaching methods (how). This framework may contribute to planning and implementing more inclusive standardization education programs.
\end{abstract}

Keywords Standardization education · Technology standards · Technology education · Curriculum design · National standardization policy

An Earlier version of this paper was presented at the third European Conference on Management of Technology in Nice, France on 17 Sept 2008.

D. G. Choi $(\bowtie)$

Korean Standards Association, 701-7 Yeoksam-dong, Gangnam-Gu, Seoul 135-513, Korea e-mail: dgchoi@ksa.or.kr

D. G. Choi

Department of Management of Technology, Sungkunkwang University, Seoul, Korea e-mail: wisemot@skku.edu

H. J. de Vries

Rotterdam School of Management, Erasmus University, Rotterdam, The Netherlands 


\section{Introduction}

The socio-economic impact of standardization has been widely acknowledged with the expansion of global trade, regional integration, multilateral and bilateral free trade agreements, and implementations of information and communication technology. Prior research on standardization has extensively been pursued for the past few decades by various research communities of engineering, economics, business, technology management and education (de Vries 2002). The research topics sought so far have ranged from its historical cases and development (Glazebrook 1931; Lockwood 1934; Vu 2006); business strategies and tactics in standardization (Besen and Farrell 1994); socio-economic functions of technical standards for innovation (Blind 2004; Centre for International Economics 2007; DTI 2005; EC 2008; WTO 2005); battles between competing industry standards (Shaprio and Varian 1999; de Vries 2006); intellectual property rights and standardization (Blind and Thumm 2004); information and telecommunication standardization (Jakobs 2001, 2005), standardization within public policy (Greenstein and Stango 2007), more recently, to standardization education (ASTM 2003; Choi et al. 2009; de Vries and Egyedi 2007; Hesser and Czaya 1999; Kurokawa 2005; M\&E Consultants 2001; Simons 1999; Spivak and Kelly 2003; Stern 2003).

Standardization education herein refers to education about technology standards, their development process and impact (de Vries 2008). Tassey (2000) provides general categories of these standards - product-element standards versus non-product standards, and quality/reliability standards, information standards, compatibility/interoperability standards, and variety reduction standards. Compared to the standardization education programs in post-formal (in-employment) education setting, standardization education in formal (pre-employment) education setting has risen rather recently. For instance, in 1947, the American Standards Association (former ANSI) conducted a five-day seminar for engineers committed to corporate standards and for educators planning a college instruction course on industrialization. In the 1970s, most developed countries were reported to offer specialized courses on company standardization and general courses to raise student awareness of standards and standardization for future generations of engineers and technologists (Verman 1973). Up to the decade of 1990s, standardization education tended to be restricted to post-formal education in the form of in-employment training, the education programs for business experts, government officials, and standardization committee members and engineers in most countries (Choi et al. 2009). But programs for formal education were in short supply and rarely observed. In as late as the early 2000 s, government agencies and national standardization bodies in some nations converted their concerns to formal or pre-employment education, thereby introducing standardization education programs into schools and colleges (Kurokawa 2005; de Vries and Egyedi 2007). Germany, Korea, Japan, UK, USA, and Viet Nam endeavored to integrate education into part of their national standardization strategies and emphasized the formal standardization education (ANSI 2005; BSI 2003; Choi et al. 2009; DIN 2004; JISC 2006; KATS 2006). Such pedagogical pursuit of standardization education is further reflected in common policy instructions of regional organizations such as the European Commission (EC) and the Asia Pacific Economic Cooperation (APEC) (APEC 2006; EC 2008b). The APEC Ministers encouraged member economies to develop a teaching curriculum and materials to address the significance of standardization (APEC 2006) and the Council of the European Union also encourages the members to make efforts to better familiarize students with the strategic benefits and challenges of standardization (EC 2008b). In the case of APEC, this is part of their trade policy, and in the EU, of the innovation policy (EC 2008a). Under 
these policy instructions of the nations and regional bodies, development of adequate curricula and teaching content materials are urgently required.

To date, research on standardization education has been pursued by two different camps: the technology education community, a group devoted to encourage research and development in all aspects of technology education (de Vries 2005b; Jones 2003; Toral et al. 2006, 2007) and the standardization community, a group devoted to advance knowledge and research in all aspects of standards and standardization (de Vries 2005a; de Vries and Egyedi 2007, Hesser and Siedersleben 2004; Kurokawa 2005). While the standardization community tries to identify the needs and requirements of standardization education as independent subject, the technology education community deals with standardization as a distinct module or component suited to different levels of technology education curricula.

The technology education community noted that technological knowledge has a normative component that scientific knowledge lacks for, and students of technology education therefore need to learn that standards and other normatively determined types of technological knowledge form an integral part of what technologists are expected to acquire (de Vries 2005b). In this vein, curriculum designers have regarded standardization as a module for or component of different levels of technology education. In a secondary school curriculum of technology education, an appropriate curriculum may include procedural knowledge of producing and applying a solution that can fulfill established requirements of commercial or safety standards (Jones 2003). In an undergraduate curriculum of electronic engineering, standards and legal regulations were surveyed comparatively important (Toral et al. 2007). In a study designed for a graduate curriculum of the information and communication technology (ICT) area, knowledge of standardization and documentary sources were registered as major content items by participating instructional professionals (Toral et al. 2006). Although these studies have highlighted standardization as a content module of technology education for different levels, there has been little literature available on all-inclusive curricula in standardization education from primary to higher even to post-formal education.

The standardization community accentuates the necessity of standardization education on the part of industrial and governmental sectors in the pre-employment phase as well as in the in-employment phase. Japanese industry and government attempted to remedy the shortage of standardization professionals and educate future standardization experts by means of structured standardization education programs (Kurokawa 2005). Likewise de Vries (2005a) developed a standardization education curriculum based on tasks and competences needed. de Vries and Egyedi (2007) listed a range of components of standardization education based on the 2nd workshop of International Cooperation for Education about Standardization (ICES): the needs and learning objectives for standardization education, and comparison of standardization education curricula for higher education. Their research clearly defined why standardization education is needed and what should be taught under standardization education programs, but did not specify what ought to be coordinated among all levels of education. Choi et al. (2009) highlighted that standardization education policies of twenty countries are similar in their common interest in putting standardization education high on the policy agenda, whereas different in their specific target groups of and approaches to standardization education, representing their dissimilar socio-economic infrastructure per country.

On the whole, however, none of these studies have fully considered elaborately implementing standardization education policies of the nations and the regional bodies mentioned earlier, thus neglecting to address development of adequate curricula and teaching content materials about standardization (ANSI 2005; APEC 2006; BSI 2003; Choi 
et al. 2009; DIN 2004; EC 2008; JISC 2006). Moreover, there still remains the problem of how to put those standardization education policies into practice, and furthermore how to develop and implement hierarchically structured and functionally unified standardization education programs from primary to post-formal education.

The present paper aims to fill the gap between the policy and its execution by providing policy makers and educators with implicit and explicit suggestions derived from an empirical analysis and comparison of standardization education practices worldwide. For the precision of this paper, we define 'standardization education' as 'education about the contents, importance and implications of industry standards and standardization'. In its technical use, a standard refers to an approved specification of a limited set of solutions to actual or potential matching problems, prepared for the benefits of the party or parties involved, balancing their needs and intended and expected to be used repeatedly or continuously, during a certain period, by a substantial number of the parties for whom they are meant (de Vries 1997). Under this definition proposed here, a standard usually refers to a technical standard, and is implicitly extended to cover the notion of specifications for services or management systems. However, in this paper, it is not used in the sense of educational standards, a formulation of the whole contents of curricula, as is the case with the USA Standards for Technological Literacy. Rather, this paper addresses the emergence of standardization as content of technology education at all levels of education, both in formal and in post-formal education. More specifically, this paper aims to examine educational practices by segmenting learning objectives based on dissimilar target groups of all levels of education and to propose a framework for standardization education. The framework includes the questions of who (target groups), why (learning objectives), where (program operators), what (teaching contents), and how (teaching methods) of standardization education. Additionally, good practices at different levels are identified in the framework for further reference. This study is new in analyzing these practices based on the segmented educational factors (who, why, what, how) and mapping them into a framework, and therefore may be beneficial for educational practitioners and policy makers to advance technology education.

\section{Research methods}

Online surveys, offline interviews, and face to face meetings are used to explore how the standardization education programs are being developed and implemented in different countries. For each of the investigation methods, a standard format of questionnaire has been used to collect detailed information of the education programs: (1) program title, (2) program operator, (3) program target groups, (4), learning objectives, (5) program operation years, (6) program operation summary, (7) textbook/curriculum summary, (8) lessons learned, as well as (9) contact information.

To collect information in the APEC region a survey was sent to the country representatives of its Sub-Committee on Standards and Conformance (SCSC) in addition to face to face interviews and meetings, and in other regions a literature review and online interviews were conducted. For effectiveness of the survey process, the present paper categorizes the standardization education programs by its target groups ('who') into two major categories: Formal education $(\mathrm{F})$ and Post-Formal education $(\mathrm{P})$ modified from a previous research (Choi et al. 2009). Formal education (F), or pre-employment education, is divided into 4 sub-categories: primary education (F1), secondary education (F2), and higher education composed of undergraduate (F3) and graduate education (F4). The postformal education $(\mathrm{P})$, or in-employment education, is classified into eight sub-categories 
Table 1 Summary of 118 education practices

\begin{tabular}{ll}
\hline Category & Number of practices \\
\hline $\begin{array}{l}\text { General promotion activities } \\
\text { Formal education I-primary } \\
\text { and secondary (F1, F2) }\end{array}$ & 16 cases ( 8 detailed sheets) \\
$\begin{array}{l}\text { Formal education II-higher } \\
\text { education (F3, F4) }\end{array}$ & 27 cases (19 detailed sheets) \\
Post-formal education (P1-P8) & 65 cases (52 detailed sheets) \\
Summary & 118 cases ( 88 detailed sheets) \\
\hline
\end{tabular}

such as business executives (P1), business working level staff (P2), government officials (P3), standards committee members (P4) etc. as shown in the second column of 'target groups' in Annex B.

As a result, the survey collected 118 standardization education practices from 21 countries worldwide; 88 cases of them have secured detailed information enough to compare each other for hierarchic segmentation-program name, program operator, target audience, learning objectives, operation year, number of participants, course length, and textbook (syllabus) summary. The 118 cases includes 16 general promotion programs, 10 primary/secondary education programs, 27 higher education programs, and 65 post-formal education programs as summarized in Table 1. The programs are collected from 12 regional or international organizations (e.g.: APEC, EC, ICES, IEC, ISO) and 21 different countries, including Egypt, France, Japan, Korea, Netherlands, Sri-Lanka, Turkey, and UK.

The full descriptions of acronyms and abbreviations which are used in this paper are provided in Annex A. Annex B provides the list of 118 standardization education practices. Numbers with '\#' mark in the text of this paper refer to the sources listed in Annex B. In order to identify core components of the education curriculum, the paper reviews and analyzes the collected information. We subsequently describe target groups (who), learning objectives (why), program operators (where), teaching contents (what), and teaching and assessment methods (how) of standardization education can be performed and finally we propose a framework for standardization education and list some policy reflections.

\section{Analysis of different approaches by target groups (who), learning objectives (where) and program operators (where)}

\section{General promotion programs}

International organizations pay more and more attention to standardization education and try to reach out to universities and academia as listed in Annex B \#103-\#118. International standardization organizations like the International Organization for Standardization (ISO), the International Electrotechnical Commission (IEC) and the International Telecommunication Union (ITU) are examples of this. ISO created a biannual Award for Higher Education in Standardization to encourage and recognize successful programs in higher education on standardization in 2007 as well as ISO e-learning program (Gerundino 2005; ISO 2007). IEC has developed Lecture Series I (2005) and II (2007) to be used for any education purposes and also published a paper collection of 'International Standardization as a Strategic Tool', comprising the commended papers from the IEC Centenary Challenge (Egyedi 2007; Purcell 2005). ITU initiated cooperation with universities-regular 
consultation meetings and online information exchange to promote education about standards in universities.

APEC has been conducting a Strategic Standards Education Initiative to develop case studies and curricula, and then a textbook (Choi 2008; www.wisestandard.org). Also, the International Federation of Standards Users (IFAN), the Standards Engineering Society (SES; www.ses-standards.org), and the European Academy for Standardization (EURAS; www.euras.org) are contributing to standardization education activities.

National standardization organizations and related agencies, in cooperation with educational institutes, also increasingly organize alike seminars. DIN in Germany, for instance, hosted the 'Conference on Standardization in Higher Education' 26 March 2009 to discuss the role of standardization in higher education; the conference was attended by 40 participants from various sectors including the Federal Ministry of Economics and Technology, DIN and universities. NIST, USA, organized a similar workshop 'Promoting Education about Standardization in North America' on 8 May 2009, to review and discuss current status and future direction of standardization education. The workshop involved around one 100 participants including governments, standards developing organizations, and dozens of university representatives.

Most notably, the International Cooperation for Education about Standardization (ICES; www.standards-education.org), which is the first and only international forum for standardization education, was formalized in 2008. The forum looks like a good venue for networking between educators, policy makers, standardization bodies and industry to pursue further cooperation for standardization education. The mission of ICES is to promote education about standardization and improve its quality and attractiveness for all stakeholders, and the ICES Fact Sheet includes the following objectives:

- Develop and maintain an interdisciplinary network of people interested in education about standardization

- Facilitate the development of policies and infrastructures to support education about standardization (e.g., in nations, regions, worldwide, industries, companies)

- Seek cooperative relationships with organizations that provide training and education in this area

- Professionalize education about standardization

In line with the policy instructions by EC and APEC described in the introduction section, the standardization education activities by international organizations are expected to increase further and deserve to get attention by education experts and policy makers.

Formal: primary/secondary education programs

There are not many practices in primary/secondary education level in this area, but some countries already have done a significant job for children in primary and secondary schools. We collected ten education practices from six countries-Japan, Korea, Philippines, Thailand, Turkey and UK as listed in Annex B \#1-\#10.

The operators of these ten programs are all either governments or national standards bodies including METI (Japan) or TISI (Thailand). In order to identify implications of the experiences in primary/secondary education, we categorized the ten cases by two viewpoints: (1) level of intensiveness (how intensive? one time event or modules for a subject?); (2) level of expansion (how many schools? one school or nation-wide?) as summarized in Fig. 1.

The most common approach in this level of education appears to be organizing an event to involve many students in a contest (\#5 Philippines-BPS) or a mixture of contest plus 


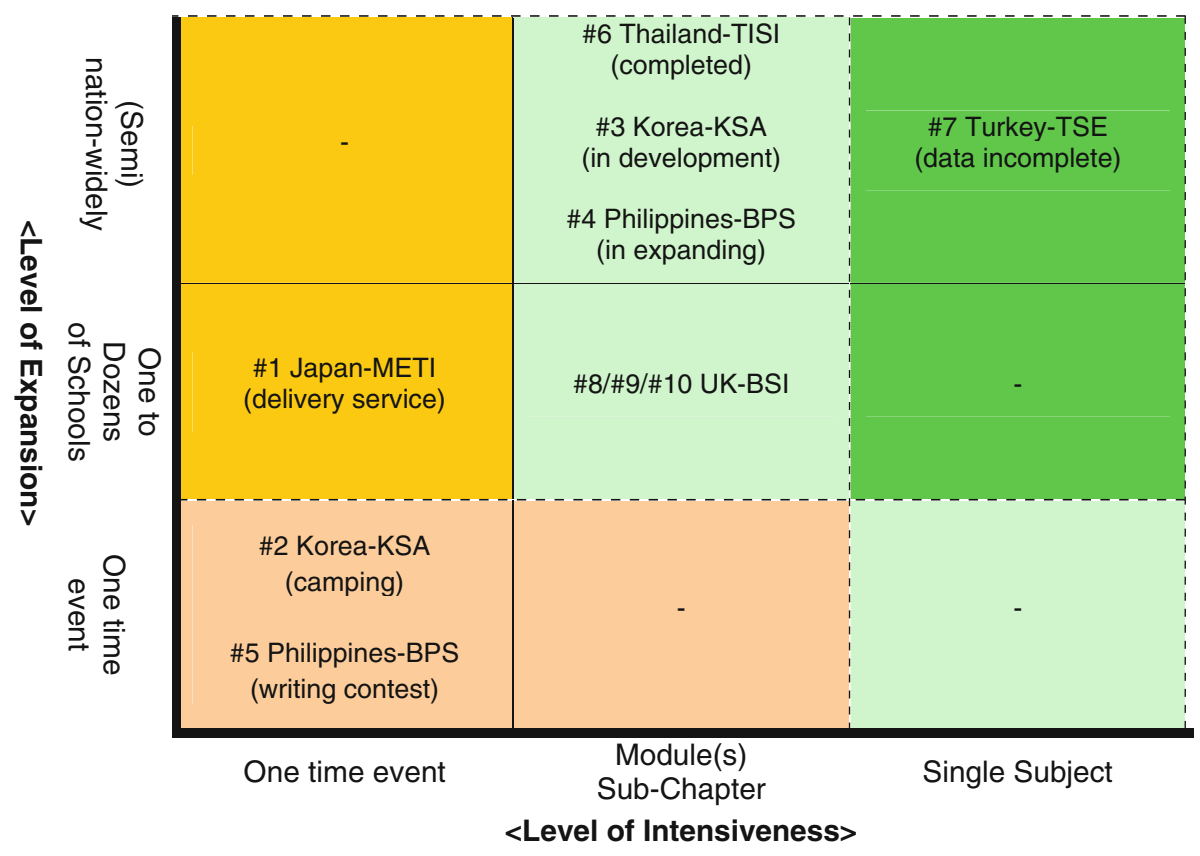

Fig. 1 Analysis of primary \& secondary education cases

lectures (\#2 Korea-KSA). In short term, the education on demand service (\#1 Japan-METI/ JSA) seems to be a creative niche approach for not only primary/secondary education but also other types of education. The 'Standards Olympiad' organized by Korea (\#2 KSA) is a two day camping program consisting of lectures and group contest activities, in which 300 (100 groups) children participated in 2007 (KSA 2007a). The Philippines (BPS) organized a 'Standards Essay Writing Contest' (\#5) to celebrate World Standards Day in 2006. Japan (\#1 Japan-METI,) provides a short special lecture program for schools 'on demand'. Per request, they do provide a lecture of $100 \mathrm{~min}$ or less about the importance of standards in daily life and in society. In 2006, 1,351 students from 25 schools took the class.

Thailand takes this event type approach, but marks outstanding records with its numbers of participating students, teachers and schools. The Thai national standards body TISI operated a nation-wide education project 'Integrating Standardization in Education' from 2003 to 2006. The project focused on training of teachers, and operated several types of contests. In total, 2,354 teachers (from 2,202 schools) and 444,600 students participated in the project.

Korea (\#3) and Philippines (\#4) developed modules or a chapter targeting to become part of formal curriculum of primary or secondary schools. Korea (\#3 KSA) is developing a sub-chapter for a secondary school textbook for technology, the chapter is planned to be selectively taught in class from 2010 nation-wide. Philippines (\#4 BPS in DTI) has developed four modules/products for students, and also seven teaching notes on four products to teach students.

The British Standards Institute BSI $(\# 8,9,10)$ provides various modules for primary and secondary school class fully via its education-dedicated website (www.bseeducation.org). BSI promoted the website to all primary and secondary schools in the UK. The website provides relevant teaching materials and games well designed for its target students and teachers, and the hits of the education site in average is no less than 51,000 per month (2007) (BSI 2007). 
Turkey (\#7) developed a textbook on standards and quality management for this level of education. Almost 15 years ago (TSE 1994), the national standards body TSE initiated an education project primarily for high school students and then the Ministry of Education took over. Nowadays, this is embedded in the Turkish education system as a part of the official curriculum.

These ten different cases display the dissimilar approaches and implementation experiences in different countries, and they could be used as benchmark practices when educators and policy makers prepare any education programs for the primary and secondary level.

Formal: higher education programs

As Choi et al. (2009) described, the APEC economies assign highest priority to the university level of standardization education. At this level, there exist more activities comparing to primary/secondary schools. We have collected and analyzed 27 practices as listed in Annex B \#11-\#37.

The operators of higher education are diverse, unlike the programs of primary/secondary education, including governments, standardization related institutions, consulting companies and, last but not least, universities themselves. In order to identify implications and find good practices, we categorized them using two viewpoints: (1) Level of intensiveness (How intensive? Does the course provide a single subject or a few different subjects related to standardization?) (2) Level of expansion (How many universities are using the same textbook, modules or curriculum? Is it transferable to other institutions?), see Fig. 2.

The EU (\#17) (Hesser et al. 2007) and ISO DEVCO (\#23) (ISO 1987) practices are not education programs but a project and a textbook respectively. The EC funded project ' $E U$ Asia Link-Standardization in Companies and Markets' is an eye-opener to the people when they first see the 718 pages hardcover textbook. Dozens standardization experts from universities, companies and standardization organizations were involved to develop the textbook, e-learning modules, and pilot education program. The textbook is on sale, but the e-learning site is open for free for universities that sign a contract with the Helmut Schmidt University in Hamburg, Germany. Companies and other organizations have to pay a fee. The ISO DEVCO's deliverable 'Development Manual 4-Teaching of standardization on

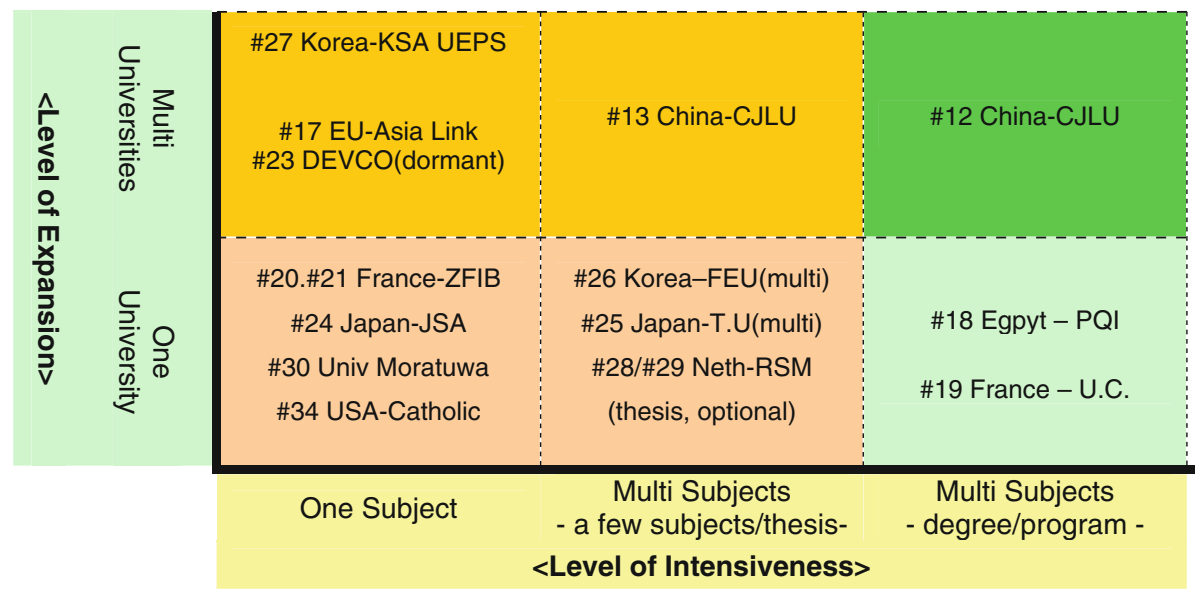

Fig. 2 Analysis of selected seventeen cases in/for higher education 
institutions of higher learning' was published in 1987 mainly for developing economies, but is outdated and not being widely recognized or used now.

The most common approach is to provide students with a single subject-usually two or three credits for one semester. These are located in the left column. An interesting case is Korea's UEPS (\#27 University Education Promotion on Standardization,) because of its semi-nationwide outreach (KSA 2003, 2006, 2007b). The UEPS is characterized by a common textbook, a team-teaching arrangement, a database and wide participation by various types of students. The program operator KSA provides the common textbook 'Future Society and Standards' to all the students of partner universities for free. Also, KSA assists universities to prepare a syllabus and to arrange external speakers; most classes are lectured by the invited outside speakers from businesses, standards organizations or research institutions. Each semester, KSA circulates a questionnaire to both teachers and students to collect feedback about the program. Around 7,500 students in 49 universities participated in the program in 2007 and 5,948 students in 48 universities in 2008. The spectrum of students is broad-from freshman to senior, from engineering to management, from choosing it as an elective to as required for a specific major.

The other four courses in the left category in Fig. 2 are the Catholic University of Washington (\#34), the ZFIB course (\#20, \#21), JSA's MBA program (\#24), and the course at the University of Moratuwa (\#29). The Catholic University provides a course 'Strategic Standardization' for graduate students in engineering; the course requires students to prepare a research paper related to standardization (Purcell and Kelly 2003; Purcell 2006). The French firm ZFIB operates two types of courses-'Standardization: a tool for Competitive Intelligence' and 'Standardization: a tool for Openness' also for graduate students in engineering; ZFIB provides the courses on demand for universities. JSA offers the 'Standardization for business solution' course for MBA students, an $18 \mathrm{~h}$ course using a team-teaching method. The University of Moratuwa, SriLanka, offers 'Quality Management \& Standardization' in its MBA in Management of Technology Program; the professor from Moratuwa suggests the course is suitable for Management of Technology and Information Technology. The Tokyo University of Agriculture and Technology (\#25) provides an MOT program, 'Strategic management of industrial standardization and intellectual property' at its Professional Graduate School of Technology; the MOT program provides multiple subjects from standardization policy and strategy to specific technology standards or case study as described. The Rotterdam School of Management, Erasmus University (\#30) offers an 'Innovation and Standardization Management' Masters course in its Department of Management of Technology and Innovation; the Erasmus University also encourages students to write their master thesis about standardization.

The more intensive courses that provide students with two or more subjects related to standardization are located in the center column. The graduate courses of CJLU, MEE (\#13, Mechanical and Electronic Engineering disciplines) and TTMM (Testing Technology and Measuring Meters disciplines), which are relatively less intensive than its undergraduate course SQM, provide three subjects; MEE and TTMM require 2.5 years to graduate and the number of students from MEE and TTMM is about thirty every year.

The most intensive three programs which are operating a single degree or program exclusively for standardization (usually including quality control together) are listed in the most right column in Fig. 3. Most intensive and impressive case is CJLU (\#12 China Jiliang University). Its undergraduate course SQM (Standardization and Quality Management) provides seven different courses and two additional special courses. The SQM course is for bachelor degree and requires four years to graduate. In total, 592 students graduated in 20032006 and more than $90 \%$ of them are working in the field of standardization; it is probably 


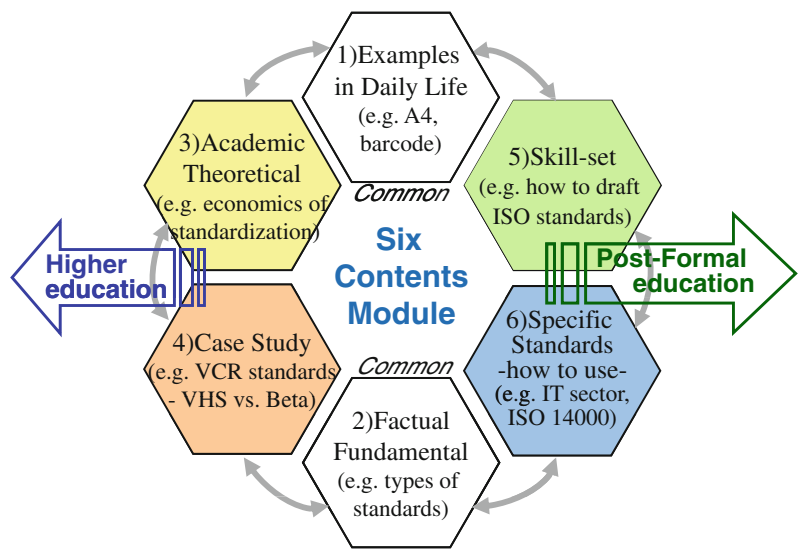

Fig. 3 Segmentation of contents modules for standardization education

possible because China is a huge economy whose central as well as local authorities need a lot of employees compared to other market economies. It is reported that some universities in China are using publications and modules developed by CJLU. Two other intensive courses are the PQI's program for post graduate degrees in Egypt (\#18), and University of Technology Compiègne's courses in France (\#19). The latter two courses are covering a combination of standardization, quality management, certification and metrology.

Above, we mentioned the ISO Award for Higher Education in Standardization. The six finalists in 2007 were China-CJLU (the final winner \#12,\#13), Egypt-PQU (\#18), FranceUC (\#19), Japan-TU (\#25), Korea-KSA/UEPS (\#27), and Netherlands-RSM (\#28, \#29). It is not surprising that ISO gave its first prize to the China-CJLU which operates the most intensive program. The Netherlands-RSM became the winner of the 2009 ISO higher education award.

It is noteworthy that six graduate courses (F4) - the cases of Tokyo University of Agriculture and Technology, RSM Erasmus University, Catholic University of Washington, ZFIB, JSA and Moratuwa-are targeting students in MOT or MBA, and focus on how standardization functions as a strategic management tool. In principal, standardization is interrelated with technology, management, administration and its education is better accepted when it is both underpinned with academic theory and is based on evidence and experience of business practices. With the interdisciplinary characteristics, at graduate level, standardization education seems to fit well as a part of an MOT curriculum. The more intensive courses seem to be feasible when the programs are strongly supported by either school strategy or outside sponsors such as education ministry or standardization organization.

\section{Post-formal education programs}

Many standardization organizations in 'old' industrialized countries have provided various post-formal education programs for decades to meet the demands of industry. Countries that industrialized more recently take up similar activities now and also some developing countries become more active in this field. We make an effort to also analyze typical postformal education practices also because it is constructive to clarify commonalities and differences between formal and post-formal education. We note that the post-formal education programs for standardization are well developed and implemented not only in 
developed countries but also in developing countries. The programs are not so much different from one and the others-for example, most countries have programs for industry experts, standardization committee members, national delegates for international standardization organizations, standardization organizations staff or laboratory engineers, and government officers. We collected 65 practices in \# 38 to \#102 of Annex B from sixteen countries and international organizations, and the courses operated by ANSI, BSI and $\mathrm{KSA}$, among them, are exemplary cases to show various range of skill-up programs operated by standards organizations.

The majority of the post-formal (in-employment) education programs are operated by national standardization bodies and the programs are designed to build particular capacity or skills. Based on the 65 practices in \#38 to \#102 of Annex B, we attempt to categorize the activities or skills in post-formal education, see Table 2. The education contents (skills) can be grouped into two big categories-No. 1 to No. 7 are dealing with skills for the people having special standardization positions or tasks while the topics of No. 8-14 are more general and could be the contents for any target group in post-formal education and also in extensively formal education.

Table 2 Categorization of skills in post-formal education

\begin{tabular}{|c|c|c|c|}
\hline No. & Topics or skills & Main target groups & $\begin{array}{l}\text { Relevant practices } \\
\text { (go to Annex B) }\end{array}$ \\
\hline 1 & $\begin{array}{l}\text { Conformity assessment skills- } \\
\text { testing, assessing, and } \\
\text { documentation }\end{array}$ & $\begin{array}{l}\text { NMI, laboratories business } \\
\text { experts }\end{array}$ & \#81 \\
\hline 2 & $\begin{array}{l}\text { Administration of standardization } \\
\text { activities }\end{array}$ & $\begin{array}{l}\text { NSB, NMI, SDOs committee } \\
\text { chair/secretariat }\end{array}$ & \#48, \#49, \#82, \#85 \\
\hline 3 & $\begin{array}{l}\text { Technical standards in relation to } \\
\text { technical regulations or legislation }\end{array}$ & $\begin{array}{l}\text { Government officials NSB, NMI, } \\
\text { SDOs }\end{array}$ & $\# 38, \# 53, \# 67, \# 89, \# 100$ \\
\hline 4 & $\begin{array}{l}\text { Communication skills-chairing/ } \\
\text { moderating a meeting }\end{array}$ & Committee chair/secretariat & \#78, \#86, \#99 \\
\hline 5 & $\begin{array}{l}\text { Working across cultures—cultural } \\
\text { differences }\end{array}$ & $\begin{array}{l}\text { Committee chair, secretariat, } \\
\text { members }\end{array}$ & \#52, \#76 \\
\hline 6 & $\begin{array}{l}\text { Developing/drafting technical } \\
\text { standards }\end{array}$ & $\begin{array}{l}\text { Committee members Business } \\
\text { experts }\end{array}$ & $\# 45, \# 49, \# 53, \# 70, \# 79$ \\
\hline 7 & $\begin{array}{l}\text { Specific industry/technology } \\
\text { standards or their aspects }\end{array}$ & Specific industry experts & \#54, \#59, \#77, \#93, \#97 \\
\hline 8 & $\begin{array}{l}\text { Communication skills-language } \\
\text { (English) }\end{array}$ & All committee members & \#52 \\
\hline 9 & $\begin{array}{l}\text { Communication skills-consensus, } \\
\text { negotiation, discussion }\end{array}$ & All committee members & $\# 52, \# 72$ \\
\hline 10 & $\begin{array}{l}\text { Procedures for developing technical } \\
\text { standards }\end{array}$ & $\begin{array}{l}\text { Committee members business } \\
\text { experts }\end{array}$ & $\# 39, \# 45, \# 74, \# 75, \# 79$ \\
\hline 11 & $\begin{array}{l}\text { Standardization process, practices in } \\
\text { general }\end{array}$ & All committee members & $\begin{array}{l}\text { Many including \#40, \#60, } \\
\# 101, \# 102\end{array}$ \\
\hline 12 & $\begin{array}{l}\text { Structure of national standardization } \\
\text { system }\end{array}$ & All committee members & $\begin{array}{l}\# 41, \# 42, \# 65, \# 83, \# 88, \\
\quad \# 89, \# 91, \# 95\end{array}$ \\
\hline 13 & $\begin{array}{l}\text { Structure of international } \\
\text { standardization system }\end{array}$ & All committee members & $\# 42, \# 51, \# 80, \# 87$ \\
\hline 14 & $\begin{array}{l}\text { Basics, fundamentals about } \\
\text { standardization }\end{array}$ & All & $\begin{array}{l}\text { (many including \#39,\#84, } \\
\# 90, \# 92, \# 94)\end{array}$ \\
\hline
\end{tabular}




\section{Analysis of teaching contents (what)}

\section{Segmentation of contents modules}

In the preceding section, we have reviewed the collection of standardization education practices mainly by its target groups-primary/secondary, higher, and post-formal education in general. This section further analyzes specifically the teaching contents (what) taking into account appropriate target groups (who). Per different level of education from the previous section, we analyze learning objectives, program operation summary, and textbook/curriculum summary from the survey questionnaire sheets to identify common features of what and how in different education practices.

As pointed out by de Vries and Egyedi (2007) and Choi (2008), it is somewhat challenging to simply compare the teaching contents by only its chapter and subchapter titles. Therefore we tried to obtain course summaries, original textbooks, proceedings, presentations as much as possible (e.g. Annex B. \#7 (TSE), \#17 (Hesser-EU), \#23 (ISO), \#27 (KSAUEPS), \#28 (Erasmus), \#50-53 (KSA), \#69-80 (BSI), \#82-95 (ANSI)) (KSA 2007b; TSE 1994; Hesser et al. 2007). After the investigation of the available contents information, we are able to group the contents into six modules: Module 1> Examples in Daily Life, $<$ Module 2 $>$ Factual/Fundamental contents, $<$ Module $3>$ Academic/Theoretical aspects, $<$ Module 4> Case Studies (advanced), <Module 5> Skill-set, <Module 6> Specific standards. The next subsections provide descriptions and possible contents for the proposed six contents modules, based on what has been found in the analysis of existing courses.

These six contents modules can be further grouped into three domains for better understanding and applications of education practitioners and policy makers as shown in Fig. 3-Core common domain, Higher education oriented domain, Post-formal education oriented domain

\section{Common core domain}

The Common Core Domain includes two centrally located modules, $<$ Module 1> Examples in Daily Life, $<$ Module $2>$ Factual/Fundamental contents,. We place these two modules in the central part in Fig. 3 as they provide common core contents and are considered part of any level of education from primary/secondary education to post-formal education.

$<$ Module 1 $>$ Examples in Daily Life and $<$ Module $2>$ Factual/Fundamental contents are found in many formal and post-formal education programs, most programs include some daily examples (e.g., Barcode, Measurements, MPEG) and fundamentals of standardization. Some topics are found in all types of education materials from contests for primary/secondary students to post-formal education courses: examples from daily life, examples explaining the importance of standards, a definition of standardization. Such topics could be observed in around 40 cases and probably these are included in most courses.

\section{$<$ Module 1> Examples in daily life}

- Scope: Examples from everyday life to show that technical standards are everywhere in our lives and standards are vital for a safe and efficient society.

- Objective: Raising the general awareness level about the importance of technical standards, and standardization. 
- Target Group: All target groups-primary/secondary, higher, post-formal education.

- Observed sample contents/topics: Paper sizes (A4, A3), colors, weights, lengths, country codes, book codes, barcode, mp3 player, battery, mp3, MPEG/JPEG, smart card, CDMA/GSM.

\section{$<$ Module 2> Factual/fundamental contents (Table 3)}

- Scope: Factual or fundamental information solely related to standardization and conformity assessment itself, and rarely found in other classes.

- Objective: To raise general understanding of main concepts and about the importance of the topic.

- Target Group: All target groups_-primary/secondary, higher, post-formal education.

- Observed contents/topics.

\section{Higher-education oriented domain}

The Higher Education-oriented Domain includes two left located modules, $<$ Module $3>$ Academic/Theoretical aspects and $<$ Module $4>$ Case studies. The paper places these two modules in the left part of Fig. 3 as they are commonly found in the courses in higher education. However, elements from the Higher-Education Domain may also be used in post-formal education, either to meet specific objectives or to increase variety of an education program.

$<$ Module 3> Academic/Theoretical aspects of standardization are chiefly found in higher education. Economics of standardization, standardization and innovation, standards and IPR are commonly found in higher education in the education such cases of Annex B \#12 (China Jiliang University), \#17 (EU-Asia Link Program) (Hesser and Siedersleben 2004), \#27 (KSA-UEPS program), \#28 (RSM Erasmus University), \#30 (University of Moratuwa), and \#34 (Catholic University).

Table 3 Observed contents of $<$ Module $2>$ factual/fundamental contents

\begin{tabular}{ll}
\hline Major classification & Sub-classification \\
\hline 1. General & General-introduction, orientation \\
2. Definitions & Concepts and definitions \\
3. Functions (value) & Needs or objectives, functions and effectiveness \\
4. History & General history, evolution \\
5. Types/classifications of standards & General, by who, by how, by what \\
6. National standardization & History, policy, strategy, procedures, legal system, relevant \\
7. Regional standardization & organizations, impact and challenges, issues \\
8. International standardization & \\
9. Consortia standardization & \\
10. Company standardization & Strategy, internal standardization, external standardization \\
12. Conformity assessment & General, types and strategy, procedures, legal system, national \\
& system-accreditation, other nations, international, regional, multi/ \\
& bi-lateral, mutual recognition agreements \\
13. Consumers & Users and consumers \\
14. Government & Government and standardization \\
\hline
\end{tabular}


$<$ Module $4>$ Case studies are chiefly found and expected to be dealt with in higher education. Case teaching is usually used in higher education, and is common in graduate education. It requires students to have certain mathematical or analytical ability in such cases as Annex B \#13 (China Jiliang University), \#17 (EU-Asia Link Program), \#19 (University of Technology Compiegne), \#20-21 (ZFIB Conseil), \#25 (Tokyo University), \#27 (KSA-UEPS), \#28-29 (RSM-Erasmus University), \#30 (University of Moratuwa), and \#34 (Catholic University). Some post-formal education includes brief case studies as well.

\section{$<$ Module 3> Academic/theoretical aspects (Table 4)}

- Scope: Interdisciplinary academic contents related to standardization; standardization within traditional academic disciplines such as economics, business administration, public administration, law, engineering.

Table 4 Observed/anticipated contents of Module 3-academic/theoretical aspects

\begin{tabular}{|c|c|}
\hline $\begin{array}{l}\text { Major } \\
\text { classification }\end{array}$ & Sub-classification \\
\hline General & Academic approaches to standardization \\
\hline History & History of standardization (academic) \\
\hline $\begin{array}{l}\text { Library/ } \\
\text { information } \\
\text { science }\end{array}$ & $\begin{array}{l}\text { Library/recording management and } \\
\text { standardization }\end{array}$ \\
\hline $\begin{array}{l}\text { Human life } \\
\text { science }\end{array}$ & $\begin{array}{l}\text { Consumer protection and standardization } \\
\text { Social welfare and standardization }\end{array}$ \\
\hline Education & Education about standardization \\
\hline Sociology & Social system and standardization (academic) \\
\hline $\begin{array}{l}\text { Public } \\
\text { administration }\end{array}$ & $\begin{array}{l}\text { Regulatory policy and standardization } \\
\text { Industry/science policy and standardization } \\
\text { R\&D policy and standardization }\end{array}$ \\
\hline Political science & International trade and standardization \\
\hline Law & Law/legislation and standardization (academic) \\
\hline Economics & Economics and standardization \\
\hline Natural science & $\begin{array}{l}\text { Natural science and standardization } \\
\text { Natural science and measurement standards }\end{array}$ \\
\hline $\begin{array}{l}\text { Medicine/ } \\
\text { pharmacy }\end{array}$ & $\begin{array}{l}\text { Medicine and standardization } \\
\text { Healthcare and standardization }\end{array}$ \\
\hline $\begin{array}{l}\text { Business } \\
\text { administration }\end{array}$ & $\begin{array}{l}\text { Standardization as a strategic tool-decision } \\
\text { making, marketing } \\
\text { Global business and standardization } \\
\text { Service management and standardization } \\
\text { Innovation and standardization } \\
\text { IPR, patents and standardization (academic) } \\
\text { MBA-business case analysis Module } 4\end{array}$ \\
\hline Engineering & $\begin{array}{l}\text { Technology management and standardization } \\
\text { Technology transfer and standardization } \\
\text { Standardization in the respective engineering } \\
\text { disciplines (mechanical, construction, ICT, etc.) } \\
\text { Module } 5\end{array}$ \\
\hline
\end{tabular}


- Objective: To learn and develop academic aspects of standardization.

- Target Group: Primarily for higher education.

- Observed/Anticipated contents/topics.

- Based on an analysis of current practices and potential needs

- Some of the above topics are connected with other modules

- Comparison of textbooks in higher education is available in de Vries and Egyedi (2007)

\section{$<$ Module 4 $>$ Case studies}

- Scope: Business cases describing different aspects of standardization and conformity assessment.

- Objective: To learn about standardization and its impact in business practice.

- Target Group: Primarily for higher education.

- Observed/Anticipated Contents/Topics: Case studies of the following cases

- Electric Power (AC vs. DC)

- Internet Browser War (Netscape, Internet Explorer, and Firefox)

- VCR (VHS and Betamax)

- Cell phones (CDMA vs. GSM)

- ISO 9001 (quality management) or 14001 (environmental management) implementation

- Simplified $<$ Module $4>$ case studies can be used in $<$ Module $1>$.

- Case studies focus on specific standards, industry, technology, or companies.

- Some of the above topics could be partly duplicative with other modules.

Post-formal education oriented domain

The Post-formal Education-oriented Domain includes two right located modules: $<$ Module $5>$ Skill-set related contents, and $<$ Module $6>$ Specific Standards. The paper places those two modules in the right part of Fig. 3 as they are commonly found in post-formal education courses. However, elements of these modules may be used in formal education as well, either to meet specific objectives or to increase variety of an education program.

$<$ Module 5 $>$ Skill-related contents can be found in post-formal education in particular. The skill-set may include conformity assessment skills, administration of standardization activities, communication skills, chairing/moderating a meeting, handling cultural differences, and developing/drafting standards. Example cases are Annex B \#45 (SAC), \#49 (ISO CS), \#52 (KSA), \#57 (BPS), \#70 (BSI), \#86 (ANSI), and \#99 (UL University).

$<$ Module $6>$ Contents related to (how to use) specific standards can be found in postformal education. The common examples of such programs are about how to use IT-related standards or how to apply the ISO 9000 series of standards on quality management or the ISO 14000 standards on environmental management. The most common format in postformal education is a one or a few days of workshop or training course and it is often provided by national standardization organizations or trade associations (\#54 Korea-TTA, \#58-\#59 Singapore-SPRING, \#60 66 Chinese Taipei-NIIPIA/TAF, \#67 \#68 Thailand-TISI, \#96 101 USA-ASTM/UL) (BSMI 2007). As the training programs about specific standards like ISO 9001, ISO 14001 are popular throughout the world, we do not 
include detailed information about this type of education in our study. Some engineering departments in universities also provide industry-specific standardization education (\#26 Korea-F.E.U). Inventories of such education or training programs are available from previous research done by the Acyl and Borde (2003), Borde (2004), Center for Global Standards Analysis (2004), the EC (2002), and Krechmer (2007).

\section{$<$ Module 5 $>$ Skill-set related contents}

- Scope: Practical skills needed in standardization practices in proposing, developing, disseminating, and administrating relevant procedures. Some of these are related to general business skills like communication or negotiating, others are solely related to standardization like writing standards.

- Objective: To learn how to carry out a standardization-related task, for instance influencing the contents of technical standards by participation in standardization committees.

- Target Group: Primarily for post-formal education.

- Observed Contents/Topics:

- Developing/Drafting standards-Template

- Communication skills-Chairing/moderating a meeting

- Communication-Working across cultures-Cultural differences

- Communication skills-Language (English)

- Communication skills-Consensus, negotiation, discussion

- Conformity assessment skills - testing, assessing, and documenting

- Administration of standardization activities.

- Based on analysis of current practices in post-formal education.

- Some of the above topics could be partly duplicative with other modules.

$<$ Module 6> (How to use) specific standards

- Scope: How to implement or use one or more particular standards.

- Objective: To learn how to implement or use particular standard(s).

- Target Group: Primarily for post-formal education (also found in engineering disciplines in higher education). Often, the standard itself and its explanatory notes are included in the teaching materials.

- Observed/Anticipated Contents/Topics:

- Electronical engineering related standards and application

- Chemical engineering related standards and application

- Mechanical engineering related standards and application

- Management Systems Standards-Quality Management and application

- Management Systems Standards-Environmental Management and application

- Service standards and application

- Corporate Social Responsibility standards and application

- RFID standards and application

- A simplified overview of $<$ Module $5>$ could be used in other modules.

- Topics can be chosen per industry, technology, or products/services.

- Some of the above topics are connected with other modules. 


\section{Analysis of teaching methods (how)}

This section briefly attempts to explore the modality of teaching and the assessment of the students for the collected practices. Active teaching or learning shifts the focus from the teacher and delivery of course contents to the student and his engagement with the material. Through active learning practices and modeling by the teacher, students drop the traditional role as passive receptors and learn and practice how to capture knowledge and skills and use them.

The most common practices observed in primary/secondary education, partly mentioned by de Vries and Egyedi (2007) and Choi et al. (2009), reveal that the contest type of group activities are adopted in several countries (\#2 Korea-KSA, \#5 Philippines-BPS, \#6 Thailand-TISI) and used in the education for children. In the practices of higher and postformal education, case study and simulation (\#27 Korea-KSA/UEPS, \#28-29 Netherlands-RSM, \#34 USA-Catholic, \#48 ISO) can be used to encourage students to participate and to develop required skills.

In higher education and post-formal education, assessment of student achievement is an important part of the education program, and is associated with teaching methods. In addition to traditional test methods, alternative methods to assess student performance are observed:

- Essays, Term Papers (Higher Education-\#27 Korea-KSA/UEPS, \#28-29 Netherlands-RSM, \#34 USA-Catholic,)

- Projects, Case studies; Portfolio (Higher Education-\#20 21 France ZFIB, \#24 25 Japan-JSA/TU, \#26 Korea-FEU)

- Performances; Simulations; Peer evaluation (Post-formal— \#48 ISO, \#52 Korea-KSA).

From interviews and offline meetings within APEC SCSC, and discussion in the ICES workshops, we learn that practically all level of students prefer case studies, group activities, and learning by doing (Choi et al. 2009). Based on the overall analysis, we summarize different types of teaching methods we observed by the following two categories in Fig. 4:

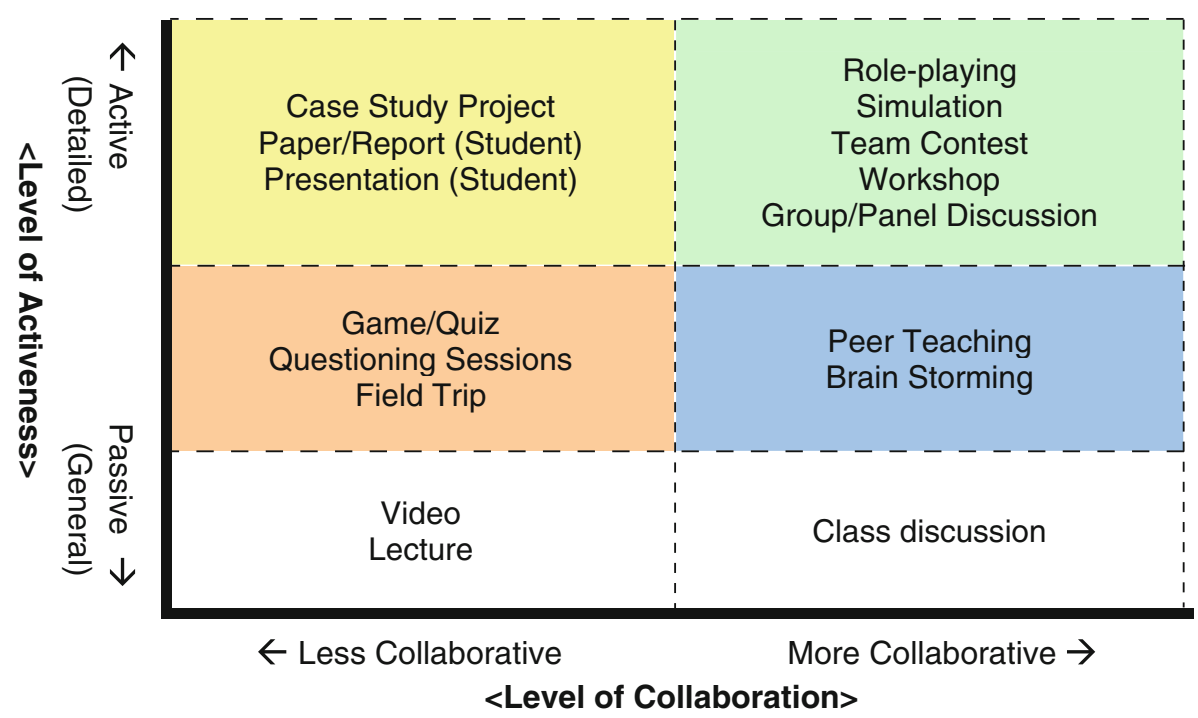

Fig. 4 Different types of teaching methods 
- Level of collaboration: Does a student learn alone or work together with others?

- Level of activeness: Does a student actively participate in classes?

\section{Framework for standardization education}

The previous sections show different levels of standardization education practices, teaching contents modules per target groups, and teaching methods from 118 practices. A framework for standardization education can be distilled by combining the major components per target groups or learning objectives for planning and operating standardization education programs, see Table 5. The proposed framework is presented for an apparent comparison of hierarchic segmentation of these programs based on the analysis of previous sections: segmented target groups (who); appropriate learning objectives (why); probable program operators (where); prospective contents modules (what); and preferred teaching methods (how).

Table 5 A proposed framework for standardization education

\begin{tabular}{|c|c|c|c|c|c|c|}
\hline \multirow[t]{2}{*}{$\begin{array}{l}\text { Who } \\
\text {-Students }\end{array}$} & \multirow{2}{*}{$\begin{array}{l}\text { Why } \\
\text {-Learning } \\
\text { objectives }\end{array}$} & \multirow[t]{2}{*}{$\begin{array}{l}\text { Where } \\
\text {-Operator }\end{array}$} & \multicolumn{2}{|l|}{$\begin{array}{l}\text { What } \\
\text {-Contents - }\end{array}$} & \multirow[t]{2}{*}{$\begin{array}{l}\text { How } \\
\text {-Methods }\end{array}$} & \multirow[t]{2}{*}{$\begin{array}{l}\text { Good practices } \\
\text { (in Annex B) }\end{array}$} \\
\hline & & & Main contents & $\begin{array}{l}\text { Subsidiary } \\
\text { contents }\end{array}$ & & \\
\hline $\begin{array}{l}\text { Primary/ } \\
\text { secondary } \\
\text { education }\end{array}$ & Awareness & Gov NSBs & $\begin{array}{l}\text { Module } 1 \\
\text {-Examples } \\
\quad \text { (simplified) }\end{array}$ & $\begin{array}{l}\text { Module } 2 \\
\quad \text { (simplified) }\end{array}$ & $\begin{array}{l}\text { Contest } \\
\text { Camping } \\
\text { Quiz } \\
\text { Game }\end{array}$ & $\begin{array}{l}\text { \#3 (Korea) } \\
\text { \#6 (Thailand) } \\
\text { \#7 (Turkey) } \\
\text { \#8-10 (UK) }\end{array}$ \\
\hline $\begin{array}{l}\text { Higher } \\
\text { education } \\
\text {-Under- } \\
\text { graduate }\end{array}$ & $\begin{array}{l}\text { Awareness/ } \\
\text { specialized } \\
\text { knowledge }\end{array}$ & $\begin{array}{l}\text { Gov } \\
\text { NSBs } \\
\text { SDOs } \\
\text { Univ }\end{array}$ & $\begin{array}{l}\text { Module } 2 \\
\text {-Fundamental } \\
\text { Module } 3 \\
\text {-Academic } \\
\text { Module } 1 \\
\text {-Example }\end{array}$ & $\begin{array}{l}\text { Module } 4 \\
\text { Module } 5 \\
\text { Module } 6\end{array}$ & $\begin{array}{l}\text { Team } \\
\text { Project } \\
\text { Presentation } \\
\text { Field trip }\end{array}$ & $\begin{array}{l}\# 12 \text { (China) } \\
\# 27 \text { (Korea) } \\
\text { \#28 } \\
\text { (Netherlands) }\end{array}$ \\
\hline $\begin{array}{l}\text { Higher } \\
\text { education } \\
\text {-Graduate }\end{array}$ & $\begin{array}{l}\text { Specialized } \\
\text { knowledge/ } \\
\text { theory }\end{array}$ & $\begin{array}{l}\text { Univ } \\
\text { Gov } \\
\text { NSBs } \\
\text { SDOs }\end{array}$ & $\begin{array}{l}\text { Module } 3 \\
\text {-Academic } \\
\text { Module } 4 \\
\text {-Case study }\end{array}$ & $\begin{array}{l}\text { Module } 6 \\
\text { Module } 2 \\
\text { Module } 5 \\
\text { Module } 1\end{array}$ & $\begin{array}{l}\text { Case study } \\
\text { Term paper } \\
\text { Workshop }\end{array}$ & $\begin{array}{l}\# 13 \text { (China) } \\
\# 17 \text { (EC) } \\
\# 18 \text { (Egypt) } \\
\# 19 \text { (France) } \\
\# 25 \text { (Japan) }\end{array}$ \\
\hline $\begin{array}{l}\text { Post-formal } \\
\text { education } \\
\text {-Gov } \\
\text {-Executive }\end{array}$ & $\begin{array}{l}\text { Strategic } \\
\text { decision/ } \\
\text { policy } \\
\text { development }\end{array}$ & $\begin{array}{l}\text { NSBs } \\
\text { SDOs } \\
\text { Gov }\end{array}$ & $\begin{array}{l}\text { Module } 2 \\
\text {-Fundamental } \\
\text { Module } 4 \\
\text {-Case study } \\
\text { (abridged) } \\
\text { Module } 3 \\
\text {-Academic }\end{array}$ & $\begin{array}{l}\text { Module } 1 \\
\text { Module } 5 \\
\text { Module } 6\end{array}$ & $\begin{array}{l}\text { Workshop } \\
\text { panel } \\
\text { discussion }\end{array}$ & $\begin{array}{l}\text { \#67 (Thailand) } \\
\text { \#89 (USA) }\end{array}$ \\
\hline $\begin{array}{l}\text { Post-formal } \\
\text { Education } \\
\text {-Committee } \\
\text { members } \\
\text {-SDO staff }\end{array}$ & $\begin{array}{l}\text { Practical skills } \\
\text { or ability }\end{array}$ & $\begin{array}{l}\text { NSBs } \\
\text { SDOs } \\
\text { Gov }\end{array}$ & $\begin{array}{l}\text { Module } 5 \\
- \text { Skill-set }\end{array}$ & $\begin{array}{l}\text { Module } 4 \\
\text { Module } 3 \\
\text { Module } 2 \\
\text { Module } 1 \\
\text { Module } 6\end{array}$ & $\begin{array}{l}\text { Simulation } \\
\text { Role paying } \\
\text { Workshop }\end{array}$ & $\begin{array}{l}\text { \#48 (ISO) } \\
\text { \#49 (ISO) } \\
\text { \#Many more, but } \\
\text { not listed all } \\
\text { here }\end{array}$ \\
\hline $\begin{array}{l}\text { Post-formal } \\
\text { Education } \\
\text {-Engineer } \\
\text {-Researcher }\end{array}$ & $\begin{array}{l}\text { How to use } \\
\text { specific } \\
\text { standards }\end{array}$ & $\begin{array}{l}\mathrm{Biz} \\
\text { Univ } \\
\text { R\&D }\end{array}$ & $\begin{array}{l}\text { Module } 6 \\
\text {-Standards }\end{array}$ & $\begin{array}{l}\text { Module } 4 \\
\text { Module } 3 \\
\text { Module } 2 \\
\text { Module } 1 \\
\text { Module } 5\end{array}$ & $\begin{array}{l}\text { Experiments } \\
\text { Practices }\end{array}$ & $\begin{array}{l}\text { \#58 (Singapore) } \\
\text { \#100 (USA) } \\
\text { Many more, } \\
\text { but not listed } \\
\text { all here }\end{array}$ \\
\hline
\end{tabular}


For formal education programs

For the primary/secondary school students, the objective is basically to raise awareness about standardization. Government or national standardization bodies are in a better position to take initiatives. For the contents, $<$ Module $1>$ Examples in Daily Life and a simplified $<$ Module $2>$ Factual/Fundamental contents are first considerations. Games, quizzes, contests and camping programs can be used in addition to lectures. Some examples of good practices in primary/secondary education are cases \#3 (KSA), \#6 (TISI), \#7 (Turkey), and \#8-10 (BSI).

For the undergraduate students in higher education, the objective is basically two-fold: first to raise awareness about standardization, and second to build specialized knowledge relevant to their major. Universities should function as main body to operate education programs, but cooperation with national standards bodies or standards developing organizations seems to be popular at this emerging stage just like the cases of China, Japan and Korea. With the evolution of standardization education, the initiative or sponsorship from national standards organizations will transfer to educational institutions. For the contents, $<$ Module 2 $>$ Factual/Fundamental contents, $<$ Module $3>$ Academic/Theoretical aspects and some $<$ Module $1>$ Examples in Daily Life are first considerations. Team projects, presentations, and field trips can be used as teaching methods in addition to lectures. Some examples of good practices in undergraduate education are the cases \#12 (China Jiliang Univ), \#27 (KSA/UEPS), and \#28 (RSM).

For the (post)graduate students in higher education, the objective is principally to build specialized knowledge and theory relevant to their major. Universities can function as main body to operate education programs, but cooperation with national standardization bodies or other standards developing organizations seems to be good practice. For the contents, $<$ Module 3> Academic/Theoretical aspects and $<$ Module $4>$ Case Studies are first considerations. Case studies, term papers, and workshops can be used as teaching methods in addition to lectures. Good practices in (post)graduate education are the cases \#13 (China Jiliang Univ), \#17 (EU-Asia Link), \#19 (Univ of Technology of Compiègne), and \#25 (Tokyo Univ).

\section{For post-formal education programs}

For government officials or business executives, the objective is mostly to improve decision making ability or policy development. National standardization bodies or other standards developing organizations can function as main body to operate education programs. For the contents, $<$ Module $2>$ Factual/Fundamental contents, $<$ Module $3>$ Academic/Theoretical aspects and $<$ Module $4>$ Case Studies are first considerations but in a very compact way because this group is sensitive to the length of the education time. Workshops, panels, and discussion can be applied as teaching methods in addition to lectures. Good practices in this category are \#67 (TISI) and \#89 (ANSI).

For members or participants of standardization committees and for staff of standards developing organizations or laboratories, the objective is principally to build practical skills or abilities needed for the job. National standardization bodies or standards developing organizations can function as main body to operate education programs. For the contents, $<$ Module 5 $>$ Skill-set is a first choice. Simulations, role playing, and workshops can be used in addition to lectures. Good practices in this category are \#48-49 (ISO CS), \#69 (BSI), and \#82 (ANSI). 
For engineers or researchers, the objective can be diverse but mainly to learn how to use specific standards. Various stakeholders including companies, universities or standards developing organizations could operate such education programs. For the contents, $<$ Module 6> Specific standards is a first consideration. Experiments and practices can be applied in addition to lectures. Good practices about how to use specific standards are not listed here because of the great number of such programs and because many of these programs are offered by commercial organizations.

\section{Conclusions and discussion}

Standardization education has been emerging in national and regional policy, emphasizing different levels of standardization education both in formal (pre-employment) and in postformal (in-employment) education. Still, it has remained unclear how to develop or implement a set of standardization education programs at the national level. The present paper was designed to fill the gap between the policy and its execution by investigating empirical data about standardization education practices worldwide. More importantly, this paper investigated how these programs observed would provide a suggestive hint on the design and development of an educational policy.

In order to explore how countries of a regional variety have implemented standardization education programs, we collected empirical data from 118 educational programs about standardization from 21 countries. The results made an array of standardization education programs worldwide both in formal and in post-formal education. These surveyed experiences showed similarity in the educational factors such as learning objectives (why) and teaching contents (what), but dissimilarity in its level of expansion and intensiveness in operation across the nations. The main observations made in this analysis are described as follows.

First, since the early 2000s, standardization education programs in formal education have been rapidly increasing worldwide. We identified 10 education practices in primary and secondary education (Japan, Korea, Philippines, Thailand, Turkey and UK), and 27 practices in higher education from various countries in different locations (China, Egypt, France, Indonesia, Japan, Korea, Netherlands, Sri Lanka, UK, USA etc.).

Second, standardization education programs partly showed similarities on the same level, but did otherwise on different levels in terms of learning objectives and program operators. For instance, the learning objective of standardization education programs for primary and secondary education was mainly to raise awareness of the importance of standardization in real-life settings, while that of higher education was to develop specialized knowledge and theory of standardization. The program operators were found to be different depending on target groups. Governmental agencies and national standardization bodies were the main initiator or operator for primary and secondary education, while universities and standards development organizations (SDOs) were equal counterpart for higher education. Generally, the support from national standardization organizations was observed to be a key to success at the initial stage of standardization education programs at all levels.

Third, the identified teaching materials of standardization education programs were clustered into six content modules: Module 1, Daily examples; Module 2, Factual information; Module 3, Academic theory; Module 4, Case studies; Module 5, Skill-set; and Module 6, Specific standards. From the six content modules, three learning orientations (target groups) were distinguished: Common and central orientation (Modules 1 \& 2), 
Higher-education orientation (Modules $3 \& 4$ ), and Post-formal education orientation (Modules 5 \& 6).

Fourth, student learners at all levels preferred case studies, group activities, and handson experiences for their teaching modalities. The most common practices employed in primary and secondary education are the contest type of group activities, as was found in Korea, the Philippines, and Thailand. Case study and simulation approaches were used both for higher education and for post-formal education in the Netherlands and the USA, and in the approach offered by ISO.

Fifth, existing formal standardization education initiatives focused mostly on a specific level of education rather than addressing all levels coherently. For instance, the programs of Turkey and Thailand concentrated on secondary schools, while China and most European countries on higher education. This unbalance in standardization education practices indicated that there is a room for further consideration in building and implementing national standardization education policies.

In conclusion, despite the increased implementation of standardization education programs in diverse countries, few of these programs, if any, have been coherently planned or comprehensively implemented thus persisting in ill-defined implementation without considering its upper and lower levels of standardization education. It may be that this disparity observed in planning and executing standardization education programs has heightened the need for a comprehensive guide that can address all-inclusive levels of standardization education. In this research, the overall survey results would indicate that the major teaching contents and methods can be segmented per target group and learning objectives, and that the need then arises for a well-informed reference for designing allinclusive curricular of education: a framework for standardization education that can provide a coherently structured and unified set of target groups (who), appropriate learning objectives (why), probable program operators (where), prospective contents modules (what), and preferred teaching methods (how). This framework proposed here includes good practices for each level of education, implemented under diverse circumstances of countries. For instance, the different approaches, adopted by Korea, Japan, the Philippines, Thailand, and Turkey, suggest that policy makers and educational practitioners who consider implementing standardization education in secondary schools could choose the most suitable option, depending on their contexts.

Although existing practices and curricula of standardization education were addressed in prior literature, these papers did not fully consider or attempt to coordinate different levels of standardization education from the comparative perspective. This paper would contribute to the current body of knowledge by suggesting a standardization education framework uniquely designed to improve the inclusiveness of standardization education at all levels of technology education. As the major findings in our study do not go into details for each level of education, studies on more in-depth specific contents development for different levels, including case studies of practices in different countries, would be required for future research. The proposed framework of this paper could contribute as a stepping stone not only for accelerating future investigation, but for designing and executing coherently unified standardization education programs at all levels for the purpose of a fullfledged implementation of technology education.

Acknowledgments This paper was partly supported by the APEC Strategic Standards Education Program (APEC CTI 21/2007T). The project was conducted by the Korean Standards Association (KSA), and the funding was provided by the Asia-Pacific Economic Cooperation (APEC) and the Korean Agency for Technology and Standards (KATS). We appreciate the enduring support from the officers of the APEC Sub- 
Committee on Standards and Conformance and KATS, and also grateful to a number of individual contributors and organizations for the collected practices.

Open Access This article is distributed under the terms of the Creative Commons Attribution Noncommercial License which permits any noncommercial use, distribution, and reproduction in any medium, provided the original author(s) and source are credited.

\section{Annex A}

See Table 6.

Table 6 Abbreviations and Acronyms

\begin{tabular}{ll}
\hline A2LA & American Association for Laboratory Accreditation \\
ADT & Advance Data Technology. LTD (Chinese Taipei) \\
ANSI & American National Standards Institute (USA) \\
APEC & Asia Pacific Economic Cooperation \\
APEC CTI & APEC Committee on Trade and Investment \\
APEC SCSC & APEC CTI Sub-Committee on Standards and Conformance \\
APEC SCSC PAGE & APEC CTI SCSC Project Advisory Group on Education \\
ASEM & Asia Europe Meeting \\
ASEM SCA & ASEM Standards and Conformity Assessment \\
ASTM & American Society for Testing and Materials (International, based in USA) \\
BSI & British Standards Institution (UK) \\
BSMI & Bureau of Standards, Metrology and Inspection (Chinese Taipei) \\
BSN & National Standardization Body (Indonesia) \\
CEN & European Committee for Standardization (Europe) \\
CJLU & China Jiliang University (China) \\
COPRAS & CO-operation Platform for Research And Standards (CEN) \\
CSA & Canadian Standards Association (Canada) \\
CPRU & Construction Planning and Research Unit (Brunei Darussalam) \\
DSM & Department of Standards Malaysia (Malaysia) \\
DTI & Department of Trade and Industry (Philippines) \\
DTI BPS & Bureau of Product Standards (Philippines) \\
EC & European Commission \\
EURAS & European Academy for Standardization \\
FSU & Florida State University \\
HKSARG & Hong Kong Special Administrative Region (Hong Kong) \\
ICES & International Cooperation for Education about Standardization \\
IEC & International Electro-technical Commission \\
IFAN & International Federation of Standards Users \\
ISO & International Organization for Standardization \\
ISO CS & ISO Central Secretariat \\
ISO DEVCO & ISO Committee on Developing Country Matters \\
ITC & Innovation and Technology Commission (Hong Kong) \\
ITU & International Telecommunication Union \\
JSA & \\
\hline &
\end{tabular}


Table 6 continued

\begin{tabular}{|c|c|}
\hline KATS & Korean Agency for Technology and Standards (Korea) \\
\hline KSA & Korean Standards Association (Korea) \\
\hline METI & Ministry of Economy, Trade and Industry (Japan) \\
\hline MOT/MOI & Management of Technology/Innovation (in graduate education) \\
\hline $\mathrm{NCC}$ & National Communications Commission (Chinese Taipei) \\
\hline NII & $\begin{array}{l}\text { National Information Infrastructure Enterprise Promotion Association } \\
\text { (Chinese Taipei) }\end{array}$ \\
\hline NMI & National Measurement/Metrology Institutes \\
\hline NSB & National Standards Body (usually corresponding to ISO, IEC) \\
\hline PSIB & Product Standards Information Bureau (Hong Kong) \\
\hline SAC & Standardization Administration of the People's Republic of China (China) \\
\hline $\mathrm{SCC}$ & Standards Council of Canada (Canada) \\
\hline SDO & Standards Developing/Development Organizations \\
\hline SES & Standards Engineering Society (Canada and USA, based in USA) \\
\hline SPRING & Standards, Productivity and Innovation Board (Singapore) \\
\hline STAMEQ & Directorate for Standards and Quality (Vietnam) \\
\hline TAF & Taiwan Accreditation Foundation (Chinese Taipei) \\
\hline TISI & Thai Industrial Standards Institute (Thailand) \\
\hline TSE & Turkish Standards Institution (Turkey) \\
\hline TTA & Telecommunications Technology Association (Korea) \\
\hline UEPS & University Education Program on Standards (Korea) \\
\hline $\mathrm{UL}$ & Underwriters Laboratories Inc. (USA) \\
\hline UNECE & $\begin{array}{l}\text { United Economic Commission for Europe (Europe, } \\
\text { former Soviet Union countries, Israel, Canada and USA) }\end{array}$ \\
\hline UNECE WP6 & UNECE working party on regulatory cooperation and standardization policies \\
\hline
\end{tabular}

\section{Annex B}

Annex B can be obtained from the author.

\section{References}

Acyl, A., \& Borde, J. M. (2003). Training and education for standardization in Europe-volume 1-survey report. Paris: Akela Business Engineering.

ANSI. (2005). United States standards strategy (USSS). New York: ANSI.

APEC. (2006). The eighteenth APEC ministerial meeting joint statement. Singapore: APEC.

ASTM. (2003). Standards education in the United States: A roundtable. ASTM Standardization News, 31(6), $41-47$.

Besen, S. M., \& Farrell, J. (1994). Choosing how to compete: Strategies and tactics in standardization. Journal of Economic Perspectives, 8(2), 117-131.

Blind, K. (2004). The economics of standards-theory, evidence, policy. Cheltenham, UK/Northampton, MA, USA: Edward Elgar.

Blind, K., \& Thumm, N. (2004). Interrelation between patenting and standardisation strategies: Empirical evidence and policy implications. Research Policy, 33(10), 1583-1598.

Borde, J. M. (2004). Training and education for standardization in Europe-survey report. In F. Bousquet, et al. (Eds.), EURAS Proceedings 2004. Aachener Beiträge zur Informatik Vol. 36 (pp. 157-170). Aachen, Germany: Wissenschaftsverlag Mainz in Aachen. 
BIS. (2003). National standardization strategic framework (NSSF). London: BSI.

BSI. (2007). The BSI annual review 2007. London: BSI.

BSMI. (2007). National strategy for standards and conformance. Chinese Taipei: BSMI.

Center for Global Standards Analysis. (2004). Report on a survey of schools of engineering in the United States concerning standards education, March 2004. Washington, DC: The Catholic University of America.

Centre for International Economics. (2007). Standards, innovation and the Australian economy. Sydney: Standards Australia.

Choi, D. G. (2008). APEC SCSC education guideline 1: Case studies of how to plan and implement standards education programs. Singapore: APEC.

Choi, D. G., de Vries, H. J., \& Kim, D. (2009). Standards education policy development: Observations based on APEC research. International Journal of IT Standards \& Stadnardization Research, 7(2), 43-63.

de Vries, H. J. (1997). Standardization, what's in a name? Terminology. International Journal of Theoretical and Applied Issues in Specialized Communication, 4(1), 55-83. (Rectification in 4(2)).

de Vries, H. J. (2002). Standardization-mapping a field of research. In Sherrie. Bolin (Ed.), The standards edge (pp. 99-121). Ann Arbor, Michigan: Bollin Communications.

de Vries, H. J. (2005a). Standardization education. In M. J. Holler (Ed.), EURAS yearbook of standardization, vol. 5, homo oecomomicus, XXII (1) (pp. 78-80). Munich: Accedo Verlagsgesellschaft.

de Vries, M. J. (2005b). The nature of technological knowledge: Philosophical reflections and educational consequences. International Journal of Technology and Design Education, 15(2), 149-154.

de Vries, H. J. (2006). Competing E-purse systems: A standards battle. Journal of Cases on Information Technology, 8(1), 1-15.

de Vries H. J. (2008). Standardisation: A business science perspective. In J. Schueler, A. Fickers \& A. Hommels (Eds.), Bargaining norms, arguing standards—negotiating technical standards. STT74 (pp. 18-32). The Hague: STT Netherlands Study Centre for Technology Trends.

de Vries, H. J., \& Egyedi, T. M. (2007). Education about standardization-recent findings. International Journal for IT Standards and Standardization Research, 5(2), 1-16.

DIN. (2004). German standardization strategy. Berlin: DIN.

DTI. (2005). The empirical economics of standards. DTI Economics Paper No 12. London: Department of Trade and Industry.

EC. (2002). EU catalogue of academic institutions involved in standardization (available at http://www. euras.org/academic-catalogue).

EC. (2008a). Towards an increased contribution from standardisation to innovation in Europe. Communication from the Commission to the Council, the European Parliament and the European Economic and Social Committee. COM (2008) 133 final. Brussels: Commission of the European Communities.

EC. (2008b). The council conclusion on standardisation and innovation in Europe, 2891st Competitiveness (Internal Market, Industry, and Research) 25.09.2008.

Egyedi, T. M. (2007). IEC lecture series: The importance of standards. Geneva: IEC (CD).

Gerundino, D. (2005). Learning-by-doing: the ISO e-learning program. ISO Focus, 2(3), 12-14.

Glazebrook, R. (1931). Standards of measurement: Their history and development. Nature, 128(3218), 17-28.

Greenstein, S., \& Stango, V. (Eds.). (2007). Standards and public policy. London: Cambridge University Press.

Hesser, W., \& Czaya, A. (1999). Standardization as a subject of study in higher education-a vision. ISO Bulletin, 30(6), 6-12.

Hesser, W., \& Siedersleben, W. (2004). Asia-link program: Development of a curriculum for 'standardization in companies and markets'. In F. Bousquet, et al. (Eds.), EURAS proceedings 2004, Aachener Beitraege zur Informatik (Vol. 36, pp. 157-170). Aachen, Germany: Wissenschaftsverlag Mainz in Aachen.

Hesser, W., et al. (2007). Standardization in companies and markets (2nd ed.). Hamburg: Helmut Schmidt University.

ISO. (1987). Development manual 4-teaching of standardization on institutions of higher learning. Geneva: ISO.

ISO. (2007, November). ISO award for higher education and education for all. ISO Focus, 4(11). ISSN 1729-8709.

Jakobs, K. (Ed.). (2001). IT standards and standardization: A global perspective. Hershey, PA: Idea Group Publishing.

Jakobs, K. (Ed.). (2005). Advanced topics in information technology standards and standardization research (Vol. 1). Hershey, PA: Idea Group Publishing.

JISC. (2006). Long term strategic guidelines innovation 25. Tokyo: JISC. 
Jones, A. (2003). The development of a national curriculum in technology for New Zealand. International Journal of Technology and Design Education, 13(2), 83-99.

KATS. (2006). National standards master plan. Seoul: MOCIE.

Krechmer, K. (2007). Teaching standards to engineers. International Journal for IT Standards \& Standardization Research, 5(2), 17-26.

KSA. (2003). International workshop to develop a standardization education model (proceedings). Seoul: KSA.

KSA. (2006). HRD in university for standards education (proceedings). Seoul, Korea: KSA.

KSA. (2007a). Standards olympiad summary report (internal document). Seoul, Korea: KSA.

KSA. (2007b). Future society and standards. Seoul, Korea: KSA.

Kurokawa, T. (2005). Developing human resources for international standards. Quarterly Review, 5(17), 34-47.

Lockwood, R. L. (1934). Railroad standards. Harvard Business Review, 12(4), 398-406.

M\&E Consultants. (2001). Report on a survey of other NSBs Educational Activities. East Barnet, Herfordshire, UK: M\&E Consultants.

Purcell, D. E. (2005). IEC lecture series: International standardization in business, industry, society and technology. Geneva: IEC (CD).

Purcell, D. E. (2006). Strategic standardization syllabus. Washington, DC: Catholic University of America, School of Engineering.

Shaprio, C., \& Varian, H. R. (1999). The art of standards wards. California Management Review, 41(2), 8-32.

Simons, C. A. J. (1999). Education in standardization-getting structured common sense into our societythe personal opinion of a standards-educator. ISO Bulletin, 30(6), 13-16.

Spivak, S. M., \& Kelly, W. E. (2003). Train the standardizers, or how to become step-by-step an expert in standardization. ISO Bulletin, 34(7), 22-24.

Stern, J. (2003). Train the standardizers, or how to become step-by-step an expert in standardization. ISO Bulletin, 34(7), 20-21.

Tassey, G. (2000). Standardization in technology-based markets. Research Policy, 29(4/5), 587-602.

Toral, S. L., Martínez-Torres, M. R., Barrero, F., Gallardo, S., \& Durán, M. J. (2007). An electronic engineering curriculum design based on concept-mapping techniques. International Journal of Technology and Design Education, 17(3), 341-356.

Toral, S. L., Martínez-Torres, R., Garcìa, F. J. B., Vázquez, S. G., \& Enrique Vargas, V. G. A. (2006). Planning a master's level curriculum according to career space recommendations using concept mapping techniques. International Journal of Technology and Design Education, 16(3), 237-252.

TSE. (1994). Standardizasyon ve Kalite (Standardization and Quality), Istanbul: Türk Standardlari Enstitüsü (TSE). (published in Turkish).

Verman, L. C. (1973). L.C. standardization-a new disciple. Hamden, CT: Archon Books.

Vu, T. A. (2006). An introduction-the history of standardization. In W. Hesser, et al. (Eds.), Standardization in companies and markets (pp. 35-60). Hamburg: Helmut Schmidt University Hamburg.

WTO. (2005). World Trade Report 2005: Standards, 'offshoring', air transport. Geneva: World Trade Organization.

\section{http links}

www.bsieducation.org (BSI Education Portal).

www.wisestandard.org (APEC Strategic Standards Education Initiative's website).

www.ses-standards.org (Standards Engineering Society).

www.standards-education.org (International Cooperation for Education about Standardization's website).

www.euras.org (European Academy of Standardisation's website). 